\title{
ACRL candidates for 1997 elections
}

\section{Be sure to vote in the spring election.}

\section{Vice-President/President-Elect}

Maureen Sullivan. Maureen Sullivan is an organizational development consultant who specializes in service to academic libraries. From 1983 to 1991 she held the position of head of Personnel Services at Yale University Libraries. Previously she was a training program specialist at the Association of Research Libraries. From 1979 to 1980 she was the assistant director of $1 \mathrm{i}-$ braries for personnel at

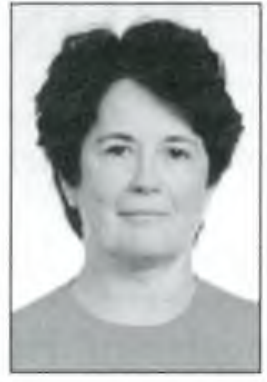

Maureen Sullivan the University of Maryland Libraries. ALA committee service includes the $\mathrm{H}$. W. Wilson Staff Development Award Jury, chair, 1985; Nominations Committee, 1986; Minority Fellowship Advisory Boarl, chair, 1989-95; Office of Library Personnel Resources Advisory Committee, chair, 1991-93; Hugh Atkinson Memorial Award Jury, 1993-97; and the CLENE Roundtable. In ACRL she has been a member of the Personnel and Staff Development Officers Discussion Group, 1978-present; University Libraries Section, Program Planning Committee, 1987; Professional Enhancement Committee, 1991present; and chair of the Search Committee for the Executive Director, 1990. She has also been active in LAMA, as the president from 1988 to 1989 , and a member of several committees. She is a member of the American Association of University Women, the American Society for Training and Development, and the College and University Personnel Association. Her publications include Developing Library Staff for the 21st Century (Haworth, 1994); Performance Analysis and Appraisal, with Robert D. Steuart,
(Neal-Schuman, 1991); and "The Changing Role of the Middle Manager in Research Libraries" (Library Trends, fall 1992). She holds a B.S. in history and an MLS from the University of Maryland.

James F. Williams MII. James F. Williams III has been dean of libraries at the University of Colorado at Boulder since 1988 . His career includes 13 years as a medical librarian and 15 years in research library administration. His research interests include health sciences librarianship, strategic planning, collection development, leadership in research libraries, and resource sharing and networking.

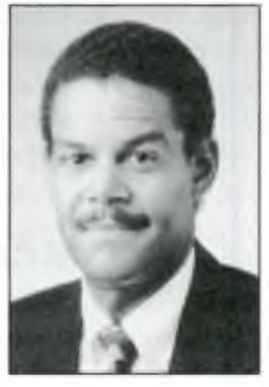

James F. Williams He has been a member of the Board of Regents of the National Library of Medicine and a Visiting Scholar and Senior Fellow at UCLA's Graduate School of Library and Information Science. He is currently a member of NASULGC's Information Technology Board, a member of the Board of Directors of EDUCOM, and a past member of the board of directors of the Association of Research Libraries. He is a member of the Board of Visitors for Libraries at the Massachusetts Institute of Technology and Southern Methodist University. He is also a member of the Visiting Committee at the School of Library and Information Science at the University of Pittsburgh. He has chaired the ACRL K. G.Saur Award Committee and he is currently a member of the ACRL Publications in Librarianship Editorial Board and the editorial board of College \& Research Libraries. He holds a B.A. from Morehouse College and the M.S. from Atlanta University.

\section{ACRL Councilor-at-Large}

Maureen Pastine, Central University Librarian, 
Southern Methodist University; Helen $H$ Spalding, Associate Director of Libraries, University of Missouri-Kansas City; Maxine $H$ Reneker, Director, Dudley Knox Library and Director, Information Services Naval Postgraduate School

\section{AAMES}

Vice-Chair/Chair-Elect: Clare B. Dunkle, Maddux Library, Trinity University; Daı'id Hirsch, Middle East Bibliographer, University of California-Los Angeles.

Member-at-Large: Binh Le, Senior Assistant Librarian, Penn State University, Ogontz Campus; Ann L. Wood, Collection Development, University of Massachusetts.

Secretary: Ngoc-My Guidarelli, Catalog Librarian, Virginia Commonwealth University.

\section{AFAS}

Vice-Chair/Chair-Elect: Sylverna Ford, Dean of the Library, Mankato State University; Dorothy Wasbington, Graduate Student, Temple University.

Secretary: Audrey Taylor, Coordinator of Reference Services, University of Houston; Heather Martin, Reference/Outreach Librarian, Wright State University.

Member-at-Large: Kathleen Bethel, African American Studies Librarian, Northwestern University; Harry Murpby, Head of Reference/Collection Management, University of Washington.

\section{ANSS}

Vice-Chair/Chair-Elect: $J$. Christina Smith, Mugar Memorial Library, Boston University.

Secretary: Cheryl C. Kugler, University Library, University of California-Irvine; Isabel del Carmen Quintana, Tozzer Library, Harvard University.

Member-at-Large: David Carpenter. Jean and Alexander Heard Library, Vanderbilt University; Sally Wilson Weimer, Davidson Library, University of California-Santa Barbara.

\section{ARTS}

Vice-Chair/Chair-Elect: Judy Sabak, Assistant Director of Libraries, Libraries of the Claremont Colleges.

Secretary: Lorelei Tanji, Fine Arts Bibliographer, University of California-Irvine; Rebecca S. Albitz, Assistant Curator for Media and the Performing Arts, New York University.

\section{CJCLS}

Vice-Chair/Chair-Elect: Cary L. Sowell, Head Librarian, Austin Community College; Jay $B$. Clark, Library Director, San Jacinto College Central.

Secretary: Terry Hancox, Director, Library LRC Cuyahoga Community College; Theresa S. Byrd, LRC Director, J. Sargeant Reynolds Community College.

\section{CLS}

Vice-Chair/Chair-Elect: Stephanie R. Bangert, Dean for Academic Resources, Saint Mary's College; Carolyn A. Sheeby, Clare and Lucy Oesterle Director of Library Services, North Central College.

Secretary: Darla Rushing, Head of Cataloging, Loyola University, New Orleans; Damon D. Hickey, Director of Libraries, The College of Wooster.

Member-at-Large: Kristin D. Vogel, Access Librarian and Assistant Professor, Sheean Library, Illinois Wesleyan University; Marilyn A. Dunn, Librarian for Public Services, Mount Holyoke College.

Member-at-Large: John Sheridan, Head Lil rarian, Tutt Library/Colorado College; Jacquelyn McCoy, College Librarian, Occidental College.

\section{EALS}

Vice-Chair/Chair-Elect: Robert Melton, Bibliographer for English, American, and Comparative Literature, Film, Theater, and Communication Studies, University of Kansas; William A. Wortman, Humanities Librarian, Miami University.

Secretary: Margaret Gordon, Assistant to the University Librarian, McHenry Library, University of California-Santa Cruz; Susan L. Peters, Coordinator for Languages and Literature, Emory University.

Member-at-Large: Margaret K. Powell, Librarian for Literature and Commonwealth Studies, Yale University; Stephen Enniss, Manuscripts Librarian and Literature Bibliographer, Emory University.

\section{EBSS}

Vice-Chair/Chair-Elect: Joan B. Fiscella, Bibliographer, University of Illinois at Chicago; Janice $M$. Wilson, Public Services Librarian, California School of Professional PsychologyLos Angeles.

Secretary: Mary M. Gilles, Business Subject Specialist, Washington State University; George 
H. Libbey, University of Detroit-Mercy, Outer Drive Library.

Member-at-Large: Francine M. DeFranco, Head of Reference, University of Connecticut; Beth G. Anderson, Director, Education Resource Center, University of Delaware.

\section{ECLSS}

Vice-Chair/Chair-Elect: Jack Fritts, Assistant University Librarian and Coordinator of Public Services, National-Louis University; Robert $P$. Morrison, Reference Librarian and Coordinator, Distance Education Library Services, Utah State University.

Secretary: Jerilyn Marsball, Assistant Schaffner Librarian, Northwestern University; Nancy Gaynor, Librarian, Illinois Institute of Technology.

Member-at-Large: Linda Barkley, Off Campus Reference Librarian, University of Redlands; Susan Barnes Whyte, Reference and Extended Services Librarian, Linfield College.

\section{IS}

Vice-Chair/Chair-Elect: Trudi Jacobson, Coordinator of User Education Programs, University at Albany, SUNY; Mary Jane Petrouski, Head of Library Instruction, Colgate University.

Secretary: Loretta Rielly, Sponsor, Instruction \& Training Team and Reference \& Research Consulting Team, Oregon State University; Deborab Tenofsky, Coordinator of Instructional Services and Programs, University of Michigan. Member-at-Large: Lynn Bailey, Reference Department Head, DePaul University; Carl Phillips, Reference Librarian, Carrier Library, James Madison University.

\section{LPSS}

For Vice-Chair/Chair-Elect: Paula J. Popma, Assistant University Librarian, Santa Clara University; Grabam R. Walden, Reference Librarian, Ohio State University, Columbus.

Member-at-Large: Janice S. Leuis, Business \& Legal Reference Librarian, Virginia Commonwealth University; Lisa Stimatz, Public Affairs/ Government Information, Pennsylvania State University-Harrisburg.

Secretary: Lucia Snowbill, University of California-Santa Barbara; Marifran Bustion, Head, Ac quisitions Dept., George Washington University.

\section{RBMS}

Vice-Chair/Chair-Elect: Richard Oram, Librarialn, Harry Ransom Humanities Research Cen- ter, University of Texas at Austin.

Member-at-Large: Peter Hanff, Coordinator, Special Projects, University of California-Berkeley; Brad Westbrook, Manuscripts Librarian/ University Archivist, University of California-San Diego.

Secretary: Lois Fischer Black, Acting Head, Historical Collections and Curator of Rare Books and Manuscripts, The New York Academy of Medicine; Jobn Hoover, Head, Special Collection/Rare Book Librarian, St. Louis Mercantile Library Association.

\section{SEES}

\section{Vice-Chair/Chair-Elect:}

Tatiana Goerner Barr, Cataloger, Stanford University; Patricia Thurston, Slavic and East European Cataloger/Assistant Professor of Library Administration, University of Illinois at UrbanaChampaign.

Member-at-Large: Joanna K. Dyla, Associate Librarian/Slavic Cataloger, University of California-Berkeley; Mieczyslaw (Mischa) Buczkowski, Slavic Librarian, University of Oregon

\section{STS}

Vice-Chair/Chair-Elect: Gail Clement, Science/Information Services Librarian, Florida International University; Billie Reinhart, Science and Engineering Librarian, Cleveland State University.

Secretary: Elizabeth Brown, Catalog Librarian, Georgia Institute of Technology; Mike Haddock, Science Reference Librarian, Farrell Library, Kansas State University.

\section{ULS}

Vice-Chair/Chair-Elect: Karvle Butcher, Interim University Librarian, Oregon State University; Maureen Pastine, Central University Librarian, Southern Methodist University.

Secretary: Katbleen Gunning, University Librarian and Coordinator of Information Resources, Susquehanna University; Karen Hatcher, Dean of Library Services, University of Montana.

Member-at-Large: Jane Conrow, Associate Dean of Libraries/Library Services, Arizona State University; Ferne B. Hyman, Assistant University Librarian, Rice University; Eloise McQuown, Librarian, San Francisco State University; Leslie Wykoff, Director of Information Services, Washington State University.

(Candidates cont. on page 775) 


\section{SOME SCIENTIFIC ACHIEVEMENTS SPEAK VOLUMES}
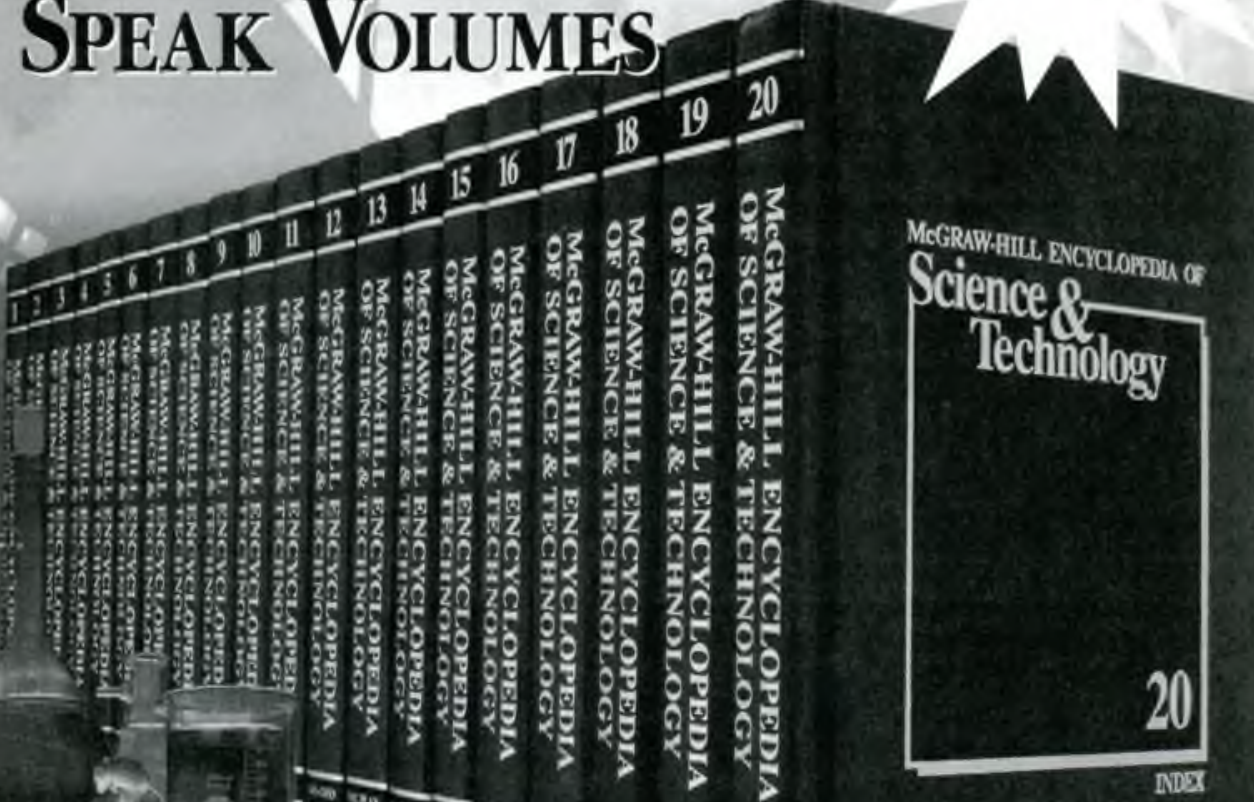

MeGRAWHIIL ENCYCIOHDU of
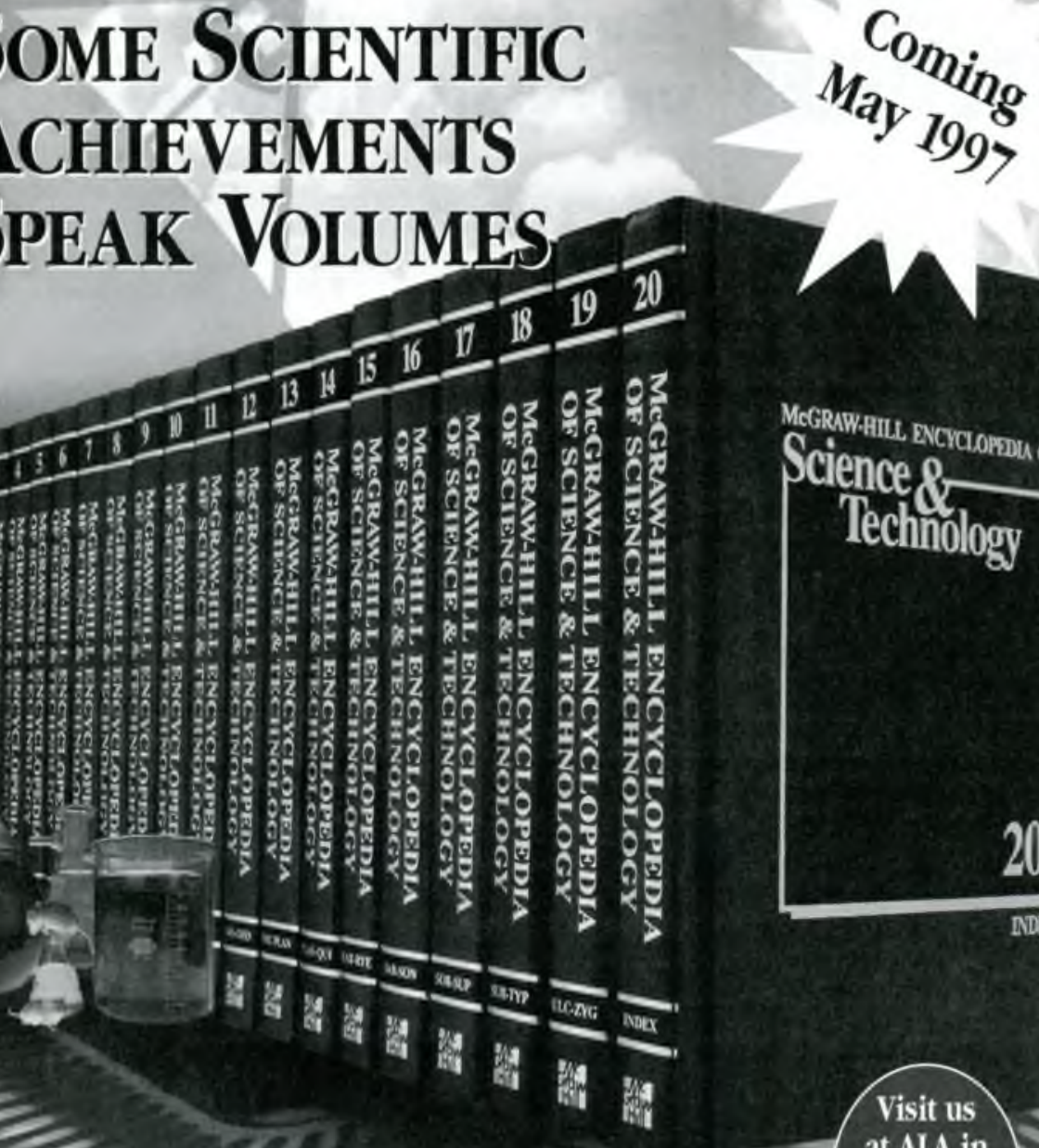

Announcing MeGraw-Hill Encyclopedia of Science \& Technology, 8th Edition

In every library there sbould be a first place students, researchers, educators and librarians turn to find information on any scientific or technical subject. A place where the inspiration for starting a research project, the supporting evidence for a paper, or the authoritative answer to an intriguing question can always be found, More than ever, the new Eighth Edition of the McGraw-Hill Encyclopedia of Science \& Tecbnology is that place, with thousands of new and revised articles and illustrations, and completely revised bibliographies. No library should be without the McGraw-Hill Encyclopedia of Science and Teclonology, Eighth Edition-the first science reference that's a scientific achievement in its own right.

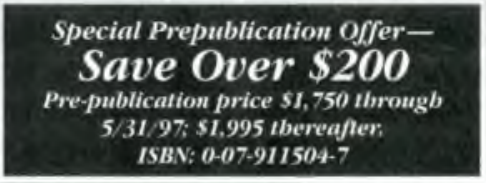




\section{More information for library advocates}

To support library advocates and help them stay involved, the ALA Washington Office is developing additional information for the ALA Web site. A summary of the status of all major library legislation (including intellectual property) at the end of the 104th Congress is now available in the November issue of the newsletter called ALA Washington News at http:// www.ala.org/washoff/alawopub.html. Analysis of election results as well as the latest information on such issues as intellectual property and the status of the fair use guiclelines will be reported in ALAWON, the ALA Washington Office Newsline, and in the newsletter. Readers may redistribute material from these publications free of charge for nonprofit purposes, with appropriate credit. To subscribe to ALAWON and receive notifications of ALA Washington News online, send the message: subscribe alawo [your_firstnamel[your_lastname] to listproc@ala.org.

For further information on these and other legislative issues as we prepare for the 105th Congress to convene in January, please contact the ALA Washington Office at (800) 9418478 or contact Lynne Bradley at leb@alawash. org.
(Candidates cont. from page 740 )

\section{WESS}

Vice-Chair/Chair-Elect: Stephen Lebmann Humanities Bibliographer, University of Penn sylvania, Philadelphia; Barbara Walden, Bibliographer, Western European Social Sciences, University of Minnesota.

Secretary: Thomas Izbicki, Resource Services Librarian, Johns Hopkins University; Charles Spornik, Coordinator, Beck Center for Electronic Collections \& Services, Emory University.

Member-at-Large: Fred W. Jenkins, Coordinator and Head of Collection Management, University of Dayton; Reinhart Sonnenburg, Literature and Languages Bibliographer, University of California-San Diego.

\section{WSS}

Vice-Chair/Chair-Elect: Kristin H. Gerbard, Catalog Librarian and Selector (Women's Studies), Iowa State University.

Secretary: Bernice Redferm, Reference Librarian/Social Science Selector, San Jose State University.

Member-at-Large: Mary Faith Pankin, Senior Subject Specialist, Gelman Library, George Washington University; Daren Callaban, Special Collections Cataloger, Morris Library, Southern Illinois University.

\section{Elegant Solutions for Preservation}

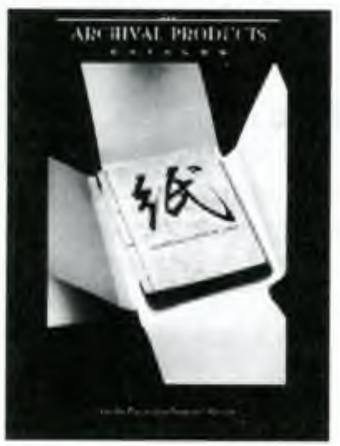

Call

for a complete catalog

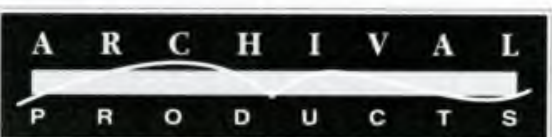

Protective Enclosures

Pamphlet Binders

Music Binders

Bound Four Flap Enclosures

Tan Archival Board

Grey/White Archival Board

Drop Spine Archival Boxes

Academy Folder

Manuscript Folder

\section{E Grand Avenue}

Des Moines, Iowa 50305

PH. 800.526.5640

FAX 515.262.6013

e-mail INET:70670,2635@compuserve.com 